\title{
PENGARUH STRUKTUR KEPEMILIKAN, FREE CASH FLOW TERHADAP KEBIJAKAN DIVIDEN PADA PERUSAHAAN ASURANSI YANG TERDAFTAR DI BEI TAHUN 2013-2017
}

\author{
Deaninda Sekar Pembayun ${ }^{1}$ \\ Email:lettu42@yahoo.co.id
}

\section{Subarjo $^{2}$}

\begin{abstract}
This study aims to find out the Effect of Managerial Ownership Structure (MNJR), Institutional Ownership Structure (INST), Free cash flow (FCF), and the Ownership Structure on Dividend Policy of Insurance Company Registered on the Indonesia Stock Exchange 2013-2017. The population in this study amounted to 55 insurance companies listed on the Indonesia Stock Exchange in 2013-2017. The samples taken were 11 companies with purposive sampling techniques. Hypothesis testing is carried out using multiple linear regression analysis. The results of the study showed that (1) Managerial Ownership Structure does not affect the Dividend Policy as evidenced by the beta coefficient (B) of 0,000, $t=-0,064<t=$ 2,008, significance probability of 0,0950>0,05 (2) ownership structure Institutional effect on Dividend Policy is proven by beta coefficient $(B)$ of $0.020, t=3.053\rangle t=2.008$ and significance probability value of $0.004<0.05$ (3) Free cash flow does not affect Dividend Policy as evidenced by beta coefficient (B) 0,001, $t=1,904$ $<t=2,008$ and significance probability value of 0,063>0,05 (4) probability Managerial Ownership Structure, Institutional Ownership Structure, Simultaneous Cash Flow affect the Dividend Policy as evidenced by the value $F=5,031>F=4,238$, the significance probability value is $0.009<0.05$.
\end{abstract}

Keywords: Managerial Ownership, Institutional Ownership, Free cash flow and Dividend Policy.

\footnotetext{
${ }^{1}$ Corresponding author: Fakultas Ekonomi, Universitas Mercu Buana, Yogyakarta

${ }^{2}$ Fakultas Ekonomi, Universitas Mercu Buana, Yogyakarta
} 


\section{PENDAHULUAN}

Peran principal dan agen atau pemegang saham dengan manajer menjadi hal yang harus dipadukan untuk pencapaian tujuan perusahaan. Tujuan perusahaan adalah meningkatkan kinerja perusahaan, yang diharapkan dapat meningkatkan kemakmuran pemegang saham dan lebih luas lagi adalah meningkatkan kepuasan dari kepentingan stakeholder. Keunikan dan pelaksanaan pengawasan dan struktur kepemilikan perusahaan akan memiliki pengaruh terhadap berbagai kebijakan perusahaan. Tingkat kepemilikan yang cukup tinggi akan memudahkan masalah pengawasan dan mensejajarkan antara kepentingan para manajer dan shareholder (Nidar 2014). Kepemilikan insider yang tinggi akan mengurangi konflik keagenan ekuitas dan memperburuk konflik keagenan utang. Meskipun demikian tidaklah jelas bagaimana struktur kepemilikan dan manajemen perusahaan berkaitan dengan “corporate leverage” dalam suatu perspektif teori keagenan.

Pada dasarnya karakteristik dari perusahaan publik adalah menyebarnya kepemilikan, yang akan membuat efektif dalam pemisahan kepemilikan residual dari keputusan pengendalian suatu perusahaan. Bila dikaitkan dengan masalah hubungan keagenan maka (Nidar 2014) menyatakan bahwa sebuah kontrak antar seseorang atau lebih (pemilik) dengan pihak lain (manajer) untuk melakukan kegiatan yang sesuai dengan tanggung jawabnya melalui pemberian wewenang untuk memutuskan suatu masalah kepada manajer akan menghasilkan hubungan keagenan. Apabila kedua pihak memiliki kepentingan yang berbeda, maka konflik kepentingan akan semakin tampak. Konflik yang terjadi antara pemegang saham dengan manajer perusahaan ini disebut dengan konflik keagenan. Munculnya konflik keagenan menyebabkan para pemegang saham harus mengeluarkan biaya untuk melakukan pengawasan terhadap perilaku manajer. Biaya pengawasan ini disebut dengan biaya agensi. Untuk mengurangi biaya agensi para pemegang saham meningkatkan kepemilikan manajerial untuk memiliki saham atas perusahaan.

Struktur kepemilikan dapat berupa kepemilikan individu, kepemilikan manajerial dan kepemilikan institusional. Penelitian yang dilakukan oleh (Mirza dan Azfa 2010) menyatakan bahwa struktur kepemilikan yaitu kepemilikan individu dan kepemilikan manajerial berpengaruh negatif terhadap pembayaran dividen. Struktur kepemilikan atas saham perusahaan juga memberikan pilihan keputusan yang lain untuk melakukan kegiatan perusahaan di masa sekarang dan masa depan. Kepemilikan manajerial mempunyai pengaruh terhadap tingkat leverage ketika meningkatnya kepemilikan manajerial yang akan diikuti dengan menurunnya leverage (utang). Kepemilikan manajerial yang besar memungkinkan para manajer dapat mengambil posisi utama dalam perusahaan untuk mengontrol keputusan leverage. Selain memiliki pengaruh pada leverage, kepemilikan manajerial dapat meningkatkan biaya agensi yang akan meningkatkan konflik antar manajer dengan pemegang saham. Sedangkan kepemilikan manajerial akan memiliki pengaruh terhadap dividen perusahaan dengan meningkatnya kepemilikan manajerial maka akan diikuti oleh menurunnya pembayaran dividen.

Kepemilikan institusional memiliki pengaruh positif pada tingkat leverage, artinya pada kepemilikan institusional yang tinggi maka leverage juga akan meningkat. (Nekounam et al. 2013) menyatakan bahwa kepemilikan institusional adalah presentase saham yang dimiliki oleh perusahaan lain dari total saham yang beredar. Perusahaan lain yang dimaksud terdiri dari perusahaan asuransi, institusi, keuangan, bank, perusahaan milik negara, dan pemerintah. 
Free cash flow atau aliran kas bebas adalah kas perusahaan yang dapat didistribusikan kepada kreditor atau pemegang saham yang tidak diperlukan untuk operasi dan investasi. arus kas ini merefleksikan tingkat pengembalian bagi penanam modal, baik itu dalam bentuk hutang atau ekuitas. Free cash flow dapat digunakan untuk membayar hutang, pembelian kembali saham, pembayaran dividen atau disimpan untuk kesempatan pertumbuhan perusahaan masa mendatang (Setiana 2013). Free cash flow disamping dengan meningkatkan hutang kemungkinan perusahaan mengambil dana dari luar sehingga perusahaan semakin sering dimonitor oleh investor baru (Tandelilin 2010). Pembayaran dividen merupakan informasi yang akan mempengaruhi permintaan dan penawaran saham perusahaan dipasar modal yang selanjutnya akan berpengaruh terhadap harga saham perusahaan. pembayaran dividen akan membuat pemegang saham mempunyai tambahan return selain dari capital gain. Hubungan antara dividen dengan kepemilikan manajerial di jelaskan melalui hipotesis aliran kas bebas oleh Jensen (1986) dalam (Sasongko dan Shaliza 2018) yang menyatakan kebijakan dividen digunakan untuk mempengaruhi kepemilikan manajerial sehingga mengurangi biaya keagenan yang berkaitan dengan arus kas bebas untuk membayar dividen kas sehingga menghindari alokasi pada tindakan yang tidak menguntungkan.

Kebijakan dividen yang optimal (optimal dividen policy) kebijakan dividen yang menciptakan keseimbangan dividen saat ini dan pertumbuhan di masa mendatang sehingga dapat memaksimumkan harga saham perusahaan Brigham dan Houston (2010) dalam (Anita dan Yulianto 2016). Kebijakan dividen perusahaan tergambar pada dividen payout ratio, yaitu presentase laba yang dibagikan dalam bentuk dividen tunai yang akan didistribusikan kepada pemegang saham. Kebijakan dividen berpengaruh untuk pertumbuhan suatu perusahaan. Apabila suatu perusahaan menginginkan menahan sebagian besar pendapatannya dalam bentuk laba ditahan di dalam perusahaan, hal ini menyebabkan pembayaran dividen semakin kecil, dengan demikian dapat dikatakan bahwa semakin tingginya dividen payout ratio maka akan semakin kecil pula dana yang akan ditanamkan kembali di dalam perusahaan yang ini berarti akan menghambat pertumbuhan perusahaan Riyanto (2001) dalam (Laili et al. 2015).

Hasil penelitian yang dilakukan oleh (Rachmawati dan Handayani 2014) yang menyebutkan bahwa kepemilikan manajerial secara parsial tidak berpengaruh terhadap kebijakan dividen, penelitian yang dilakukan oleh Hatta (2002), Mulyono (2009), dan (Ayem dan Nugroho 2010) membuktikan bahwa kepemilikan manajerial tidak berpengaruh signifikan terhadap dividen payout ratio. Kahar (2008) mengemukakan bahwa kepemilikan manajerial yang tinggi menyebabkan dividen yang dibayarkan pada pemegang saham (dividend payout ratio) rendah. Hasil penelitian penelitian Kurniawati et al. (2015) menunjukkan Terdapat hubungan yang signifikan positif antara kepemilikan institusional dan kebijakan dividen, artinya kenaikan kepemilikan institusional biasanya juga diikuti kenaikan kebijakan dividen. Sementara hasil penelitian.

Arilaha (2009) yang menemukan bahwa free cash flow tidak berpengaruh terhadap Kebijakan Dividen. Berdasarkan latar belakang masalah di atas, maka penulis tertarik untuk menguji pengaruh Struktur Kepemilikan, Free Cash Flow terhadap Kebijakan Dividen di mana Objek Penelitian pada perusahaan Asuransi yang terdaftar di BEI untuk periode 2013-2017. 


\section{TINJAUAN PUSTAKA}

\subsection{Teori Keagenan (Agency Teory)}

Teori keagenan mendeskripsikan hubungan antara pemegang saham (shareholder) sebagai principal dan manajemen sebagai agen. Manajemen merupakan pihak yang dikrontrak oleh pemegang saham untuk bekerja demi kepentingan pemegang saham. Karena mereka dipilih, maka pihak manajemen harus mempertanggungjawabkan semua (Ichsan 2013). Hubungan keagenan sebagai kontrak antara satu atau lebih orang sebagai principal dengan orang lain sebagai agent untuk melakukan layanan dengan memberikan wewenang pengambilan keputusan kepada agen. Teori keagenan memiliki asumsi bahwa tiap-tiap individu semata-mata termotivasi oleh kepentingan pribadi sehingga menimbulkan konflik kepentingan dengan pemegang saham. Adanya perbedaan kepentingan menyebabkan konflik keagenan. Konflik keagenan timbul karena para pemegang saham menilai bahwa perilaku dan keputusan manajer hanya mementingkan diri sendiri dengan ditandai adanya perilaku pemborosan biaya yang menyebabkan para pemegang saham harus mengeluarkan biaya yang lebih tinggi.

\subsection{Konflik Keagenan (Agency Conflict)}

Konflik keagenan terjadi karena pemilik modal selalu berusaha menggunakan dan sebaik-baiknya dengan risiko sekecil mungkin, sedangkan manajer (agent) cenderung mengambil keputusan pengelolaan dana untuk memaksimalkan keuntungan yang sering bertentangan dan cenderung mengutamakan kepentingannya sendiri. Namun dalam realitanya banyak terjadi "agency problem", yaitu konflik kepentingan antara manajer dan pemegang saham (Keown 2004). Agency problem juga dapat terjadi karena manajer dan pemegang saham sering kali tidak memperoleh informasi yang sama tentang perusahaan.

\section{Biaya Keagenan (Agency Cost)}

Jensen (1986) dalam Faizal (2014) mendefinisikan biaya keagenan (agency cost) sebagai jumlah pengeluaran untuk pengawasan yang dilakukan oleh pemegang saham, pengeluaran karena penggunaan hutang oleh agen serta pengeluaran karena residual loss yaitu pengeluaran biaya oleh pemegang saham eksternal untuk mempengaruhi keputusan manajer dalam memaksimalkan kemakmuran pemegang saham. Menurut Rozeff (1982) oleh Wulandari (2006) dalam Anggraeni (2017) menyatakan bahwa pembayaran dividen merupakan bagian dari optimum monitoring (biaya pengawasan) dan bonding package (biaya pengikat) yang dapat menurunkan agency cost.

\section{Kebijakan Dividen}

Kebijakan dividen adalah kebijakan yang mengatur beberapa laba bersih yang akan dibagikan sebagai dividen kepada para pemegang saham atau akan ditahan dalam bentuk laba ditahan untuk membiayai investasi kebijakan dividen dalam suatu perusahaan juga dipengaruhi oleh beberapa faktor antara lain : perjanjian hutang, pembatasan dari saham preferen, tersedianya kas, pengendalian terhadap perusahaan, Kebutuhan dana untuk investasi, fluktuasi laba. 


\section{Hipotesis Penelitian}

\subsubsection{Pengaruh Kepemilikan Manajerial terhadap Kebijakan Dividen}

Manajer mendapatkan kesempatan untuk ikut dalam kepemilikan saham dengan tujuan menyetarakan dengan pemegang saham. Melalui kebijakan ini, manajer diharapkan mempunyai kinerja yang baik serta mengarahkan dividen pada tingkat yang paling rendah. Dengan penetapan dividen yang rendah, perusahaan memiliki saldo laba yang tinggi sehingga memiliki dana integral yang relatif tinggi untuk berinvestasi dimasa depan. Apabila pemegang saham menyukai dividen tinggi maka akan menimbulkan perbedaan kepentingan sehingga diperlukan peningkatan dividen. Sebaliknya dalam konteks kepemilikan saham oleh manajerial tinggi akan terjadi kesamaan preferensi antara pemegang saham dan manajer tidak diperlukan peningkatan dividen. Semakin banyaknya saham yang dimiliki oleh manajerial maka manajemen cenderung menahan laba untuk pengembangan perusahaan. Karena dengan meningkatnya nilai perusahaan maka nilai kekayaannya sebagai individu pemegang saham akan ikut meningkat. Kahar (2008) mengemukakan bahwa kepemilikan manajerial yang tinggi menyebabkan dividen yang dibayarkan pada pemegang saham (dividend payout ratio) rendah. Penelitian yang dilakukan oleh (Hatta 2002), Mulyono (2009), dan Ayem dan Nugroho (2010) membuktikan bahwa kepemilikan manajerial tidak berpengaruh signifikan terhadap dividend payout ratio. Dan sejalan dengan hasil penelitian yang dilakukan oleh Rachmawati dan Handayani (2014) yang menyebutkan bahwa kepemilikan manajerial secara parsial tidak berpengaruh terhadap kebijakan dividen.

H1 : Kepemilikan Manajerial mempunyai pengaruh Signifikan terhadap kebijakan dividen

\subsubsection{Pengaruh Kepemilikan Institusional terhadap Kebijakan Dividen}

Kepemilikan institusional adalah proporsi saham yang dimiliki oleh pihak institusi pada akhir tahun yang diukur dalam presentase Listyani (2003) dalam Firmanda et al. (2015). Tingkat saham institusional yang tinggi akan menghasilkan upaya-upaya pengawasan yang lebih intensif sehingga dapat membatasi perilaku opportunistic manager, yaitu manajer melaporkan laba secara opportunistic untuk memaksimumkan kepentingan pribadinya Shepherd dan Scott Jr (1975) dalam Dewi (2008). Menurut Ismiyanti dan Hanafi (2003) dalam Firmanda et al. (2015) Semakin tinggi kepemilikan institusional maka semakin kuat kontrol eksternal terhadap perusahaan dan mengurangi kos keagenan. penelitian Tandelilin dan Wilberforce (2002) yang menyebutkan bahwa kepemilikan institusional berpengaruh positif terhadap kebijakan dividen karena kepemilikan institusional lebih mementingkan stabilitas pendapatan (return) melalui pembagian dividen hal ini sejalan dengan penelitian Kurniawati et al. (2015) Hasil penelitian menunjukkan Terdapat hubungan yang signifikan positif antara kepemilikan institusional dan kebijakan dividen, artinya kenaikan kepemilikan institusional biasanya juga diikuti kenaikan kebijakan dividen.

$\mathbf{H}_{2}$ : Kepemilikan Institusional mempunyai pengaruh Signifikan terhadap kebijakan dividen 


\subsubsection{Pengaruh Free cash flow terhadap Kebijakan Dividen}

Menurut free cash flow hypothesis ketika perusahaan memiliki kelebihan kas, maka yang dibutuhkan adalah proyek yang memiliki net present value (NPV) positif. Tetapi lebih baik bagi manajer untuk mengembalikan kelebihan kas pada pemegang saham dalam bentuk dividen guna memaksimumkan kekayaan pemegang saham. Hal tersebut menunjukkan bahwa dividen dapat mengurangi agency cost karena mengurangi free cash flow bagi manajer dalam (Arilaha 2009). Penelitian mengenai free cash flow dengan kebijakan dividen di Indonesia dilakukan oleh Nurdiana (2007) dan Purnomo (2008) yang menemukan bahwa free cash flow , memiliki pengaruh yang signifikan terhadap kebijakan dividen. Mollah et al. (2000) dalam Kurniawan (2011) yang menyatakan bahwa arus kas mempengaruhi rasio pembayaran dividen secara signifikan hubungannya positif, jadi apabila posisi kasnya tinggi biasanya perusahaan akan membayar dividen dengan jumlah yang besar. Kurniawan (2011) dalam penelitiannya mendapatkan hasil bahwa arus kas berpengaruh positif signifikan terhadap dividen kas. Tetapi berbeda dengan hasil penelitian yang dilakukan oleh Arilaha (2009) yang menemukan bahwa free cash flow tidak berpengaruh terhadap Kebijakan Dividen.

$\mathbf{H}_{3}$ : Free cash flow mempunyai pengaruh Signifikan terhadap kebijakan dividen

\section{METODE PENELITIAN}

\subsection{Populasi dan Sampel}

Populasi dalam penelitian ini adalah seluruh sektor perusahaan asuransi yang go public di BEI selama periode 2013-2017. Pemilihan sampel menggunakan teknik Purposive sampling dengan kriteria sebagai berikut : 1) Perusahaan Asuransi terdaftar di Bursa Efek Indonesia tahun 2013-2017, 2)Sampel yang digunakan adalah 55 sampel dari 11 perusahaan yang memenuhi data keuangan lengkap Perusahaan menerbitkan laporan keuangan secara lengkap dengan periode pelaporan tahunan yang berakhir pada 31 Desember, dan (3) Perusahaan memiliki data lengkap yang dibutuhkan dalam penelitian. Sampel yang digunakan dalam penelitian ini sebanyak 11 perusahaan.

\section{Definisi Operasional Variabel}

Variabel Dependen yang digunakan yakni Kebijakan Dividen. Variabel Independen, Kepemilikan Manajerial, Kepemilikan Institusional, Free cash flow.

a. Kebijakan Dividen (Y)

Kebijakan dividen yang diartikan dalam keputusan laba yang diperoleh perusahaan akan dibagikan kepada pemegang saham sebagai dividen atau akan ditahan dalam bentuk laba ditahan guna membiayai investasi di masa yang akan datang. Beberapa peneliti seperti Cai (2010), Mirza dan Azfa (2010), dan Ullah et al. (2012), menguji pengaruh struktur kepemilikan terhadap kebijakan dividen yang diukur dengan dividend payout ratio. Pengukuran kebijakan dividen dilakukan dengan menggunakan rumus sebagai berikut :

DPR=(Dividen per lembar saham $) /($ laba bersih per lembar saham $)$ 
b. Kepemilikan Manajerial (X1)

Kepemilikan Manajerial (managerial ownership) adalah tingkat kepemilikan saham pihak manajemen yang secara aktif ikut dalam pengambilan keputusan misalnya direktur dan komisaris Wahidahwati (2002). kepemilikan manajerial dirumuskan dengan jumlah saham yang dimiliki oleh institusi dari total saham yang beredar.

c. Kepemilikan Institusional (X2)

Kepemilikan institusional adalah persentase kepemilikan saham oleh investor institusional seperti perusahaan investasi, bank, perusahaan asuransi maupun kepemilikan lembaga dan perusahaan lain. Kepemilikan institusional memiliki peranan yang penting dalam perusahaan karena dapat mengontrol manajemen dengan pengawasan yang lebih optimal (Sheiler dan Vishny dalam Indahningrum dan Handayani 2009). Kepemilikan institusional dirumuskan dengan jumlah saham yang dimiliki oleh institusi dari total saham yang beredar.

d. Free Cash Flow (Arus kas Bebas )

Free cash flow merupakan dana yang tersedia bagi manajer sebelum keputusan untuk menginvestasikan modal (Kouki dan Guizani 2009). Pembayaran dividen dan bunga mengurangi peluang manajemen untuk mendanai proyek yang kurang profitable atau untuk keuntungan manajemen sendiri. Menurut Mirza dan Azfa (2010), kas yang dihasilkan dari aktivitas operasi perusahaan memainkan peranan penting dalam menentukan besarnya pembayaran dividen dibandingkan dengan sumber aliran kas yang lain. Sesuai dengan penelitian Mirza dan Azfa (2010) serta Thanatawee (2013) diukur dengan jumlah Aliran kas dari aktivitas operasi dengan total aset.

\section{Metode Analisis Data}

Analisis data dilakukan menggunakan berganda untuk menguji pengaruh Struktur kepemilikan Free cash flow terhadap kebijakan dividen.

\subsubsection{Uji Asumsi Klasik}

\section{a. Uji Normalitas}

Uji Normalitas bertujuan untuk menguji apakah dalam model regresi, variabel terikat dan variabel bebas keduanya mempunyai distribusi normal atau tidak. Model regresi yang baik adalah memiliki nilai residual yang terdistribusi normal atau mendekati normal (Imam 2011). Dalam mendeteksi apakah residual terdistribusi normal atau tidak yaitu dengan uji statistik non parametrik Kolmogorov-Smirnov (Uji K-S). Jika probabilitas >0,05 dapat dikatakan model normal (data terdistribusi normal).

\section{b. Uji Multikolonieritas}

Uji multikolonieritas digunakan untuk menguji ada atau tidaknya korelasi antar variabel independen dalam model regresi. Prasyarat yang harus terpenuhi dalam model regresi yang baik adalah tidak adanya multikolinearitas. Menurut Imam (2011) metode yang digunakan untuk mendeteksi multikolonieritas dengan melihat dari 1) nilai tolerance dan lawannya 2) Value Inflation Factor (VIF) pada model regresi. Nilai yang menunjukkan adanya multikolonieritas adalah nilai tolerance $\leq 0,10$ atau sama dengan nilai $\mathrm{VIF} \geq 10$. 


\section{c. Uji Heterokesdastisitas}

Uji heteroskedastisitas bertujuan untuk menguji apakah dalam model regresi terjadi ketidaksamaan variance dari residual satu pengamatan ke pengamatan yang lain (Imam 2011). Jika ada pola tertentu, seperti titik-titik membentuk pola tertentu yang teratur (melebar kemudian menyempit, bergelombang), maka mengindikasikan terjadi heteroskedastisitas.

\section{d. Uji Autokorelasi}

Autokorelasi bisa didefinisikan sebagai korelasi di antara anggota observasi yang diurut menurut waktu (seperti kata deret berskala) atau ruang (seperti data lintas sektoral) (Gujarati dan Porter 2006). Secara sederhana autokorelasi adalah keadaan di mana variabel gangguan pada periode tertentu berkorelasi dengan variabel gangguan pada periode lain. Untuk menguji ada tidaknya autokorelasi tersebut biasanya digunakan uji Durbin-Watson.

e. Uji Hipotesis

Uji Hipotesis dilakukan menggunakan model regresi linier berganda. Model analisis regresi berganda sebagai berikut :

\section{$\mathbf{Y}=\mathbf{a}+\mathbf{b} 1 \mathrm{Mnj} \mathbf{r}+\mathbf{b} 2 \mathrm{Inst}+\mathbf{b 3 F C F}+\mathbf{e}$}

\section{f. Uji Parsial (uji t)}

Uji digunakan untuk mengetahui seberapa besar pengaruh variabel independen secara parsial terhadap variabel dependen digunakan uji t. Uji statistik $\mathrm{t}$ menunjukkan seberapa jauh pengaruh satu variabel independen secara individual dalam menerangkan variasi variabel dependen.

\section{g. Uji Simultan (uji F)}

Uji f digunakan untuk menguji apakah model regresi yang digunakan adalah fit. Menurut Imam (2011), uji statistik F pada dasarnya menunjukkan apakah semua variabel bebas yang dimaksudkan model mempunyai pengaruh secara simultan atau bersama-sama terhadap variabel dependen.

\section{h. Uji Koefisien Determinasi (R2)}

Koefisien determinasi (R2) ini digunakan untuk mengukur kebaikan dari persamaan regresi berganda, yang memberikan presentase variasi total dalam variabel dependen yang dijelaskan oleh seluruh variabel independennya. R2 digunakan untuk mengetahui keeratan hubungan antara variabel independen dengan variabel dependen (Imam 2011, 83). Nilai R2 terletak antara 0 sampai dengan $1(0 \leq \mathrm{R} 2 \leq 1)$.(Martono 2015)

\section{HASIL DAN PEMBAHASAN}

\subsection{Hasil Statistik}

\subsubsection{Uji Normalitas}

Hasil pengujian menunjukkan nilai probabilitas sebesar 0,390 (lebih besar dari 0,05), maka disimpulkan bahwa penyebaran data penelitian adalah normal. 


\subsubsection{Uji Multikolinearitas}

Hasil uji multikolinearitas menunjukkan bahwa nilai tolerance dari masingmasing variabel lebih besar 0,1 atau nilai VIF kurang dari10,maka dapat disimpulkan bahwa dalam model regresi tidak terjadi gejala multikolinearitas.

\subsubsection{Uji Heteroskedastisitas}

Uji heteroskedastistas dilakukan dengan menggunakan metode scatter plot's yaitu dengan melihat ada tidaknya pola-pola tertentu. Hasil uji heteroskedastisitas terlihat tidak ada bentukan pola tertentu yang jelas, serta titik-titik menyebar di atas dan di bawah angka nol (0) pada sumbu Y. Hal ini menunjukkan bahwa tidak terjadi heteroskedastisitas.

\subsubsection{Uji Autokorelasi}

Uji autokorelasi dilakukan menggunakan uji Durbin Waston (uji DW) . Hasil uji autokorelasi menunjukkan bahwa nilai DW sebesar 1.729 telah memenuhi kriteria $\mathrm{dU}<\mathrm{d}<4-\mathrm{dU}$. Hal ini menunjukkan bahwa model regresi telah memenuhi asumsi tidak terjadi autokorelasi.

\subsubsection{Uji Hipotesis}

Untuk menguji hipotesis menggunakan analisis regresi berganda, dan diperoleh persamaan regresi berikut ini :

$$
\begin{aligned}
& Y=a+b 1 \text { Mnjr+b2Inst+b3FCF+e } \\
& Y=0,269+0,000+0,020+0,001+e
\end{aligned}
$$

\subsubsection{Uji Parsial (Uji t)}

Dari hasil uji t untuk variabel manajerial (X1) diketahui nilai t hitung sebesar $-0,064<\mathrm{t}$ tabel sebesar 2,008 dan nilai signifikan 0,950>0,05 (dengan nilai df (n-k$1)=51,0,025)$ Hal ini menunjukkan bahwa variabel kepemilikan manajerial tidak berpengaruh terhadap kebijakan dividen.

Variabel institusional (X2) nilai t hitung sebesar 3,053> t tabel 2,008,nilai signifikan 0,004<0,05 (dengan nilai df $(n-k-1)=51,0,025)$ Hal ini menunjukkan bahwa variabel kepemilikan institusional berpengaruh signifikan terhadap kebijakan dividen

Variabel Free cash flow (X3) nilai t hitung sebesar 1,904<t tabel 2,008, dan nilai signifikan 0,063>0,05 (dengan nilai $\mathrm{df}(\mathrm{n}-\mathrm{k}-1)=51,0,025)$ Hal ini menunjukkan bahwa variabel Free cash flow tidak terdapat pengaruh terhadap kebijakan dividen.

\subsubsection{UJi Simultan (Uji F)}

Berdasarkan hasil perhitungan yang ditunjukkan dari tabel IV.9 nilai signifikansi sebesar 0,009<0,05 dan nilai $\mathrm{F}$ hitung sebesar 4,238> F tabel 2,79 (d1= 3 , df2= 51) sehingga dibuktikan bahwa variabel Kepemilikan Manajerial, Kepemilikan Institusional dan Free cash flow secara simultan berpengaruh terhadap kebijakan dividen.

\subsubsection{Uji Koefisien Determinasi (R2)}

nilai Adjusted $R$ Square pada model sebesar 0,200 atau 20\%, bahwa Kepemilikan Manajerial (X1), Kepemilikan Institusional (X2) dan Free cash flow (X3) sebesar $20 \%$ sedangkan sisanya sebesar $80 \%$ diterangkan oleh variabel yang tidak masuk di dalam penelitian ini. 


\subsection{Pembahasan}

\subsubsection{Pengaruh Kepemilikan Manajerial terhadap Kebijakan Dividen}

Dari hasil analisis regresi linier berganda diperoleh nilai koefisien Regresi sebesar 0,000 dan uji parsial variabel kepemilikan manajerial diperoleh nilai t hitung sebesar -0,064> t tabel sebesar 2,008 dan nilai signifikansi sebesar $0.950<0,05$ $($ dengan nilai df $(\mathrm{n}-\mathrm{k}-1)=51,0,025)$ Hal ini menyatakan kepemilikan manajerial tidak berpengaruh terhadap kebijakan dividen atau dengan kata lain hal yang menyatakan terdapat pengaruh kepemilikan manajerial yang menyatakan terdapat pengaruh kepemilikan manajerial yang diproksikan dengan MNJR terhadap kebijakan dividen tidak diterima atau ditolak. Hal tersebut sejalan dengan penelitian sebelumnya yang dilakukan oleh Handayani (2008) penelitian menunjukkan kepemilikan manajerial secara parsial tidak berpengaruh terhadap kebijakan dividen.

\subsubsection{Pengaruh Kepemilikan Institusional terhadap Kebijakan Dividen}

Dari hasil analisis regresi sebesar 0,020 diperoleh dengan nilai signifikansi sebesar 0,004 Dan uji parsial variabel kepemilikan institusional diperoleh nilai $\mathrm{t}$ hitung sebesar 3,053>t tabel 2,008 dan nilai signifikan sebesar 0,004<0,05(dengan nilai df $(n-k-1)=51,0,025)$ Hal ini menyatakan terdapat pengaruh kepemilikan institusional terhadap kebijakan dividen atau dengan kata lain hal yang menyatakan terdapat pengaruh kepemilikan institusional yang diproksikan dengan INST terhadap kebijakan dividen diterima. Hal tersebut sejalan Kurniawati et al. (2015) Hasil penelitian menunjukkan Terdapat hubungan yang signifikan positif antara kepemilikan institusional dan kebijakan dividen, artinya kenaikan kepemilikan institusional biasanya juga diikuti kenaikan kebijakan dividen. Hal ini disebabkan oleh besar kecilnya kepemilikan institusional pada perusahaan yang setiap tahunya berubah-ubah. Pada akhirnya, perbedaan hasil dapat terjadi, artinya apabila kepemilikan institusional naik, kebijakan dividen belum tentu mengalami kenaikan juga. Secara teori, kepemilikan institusional berpengaruh terhadap kebijakan dividen dan Hal ini terbukti pada penelitian yang telah dilakukan oleh Embara (2012) yang menyatakan bahwa kepemilikan institusional berpengaruh positif signifikan terhadap kebijakan dividen.

\subsubsection{Pengaruh Free cash flow terhadap Kebijakan Dividen}

Dari hasil analisis regresi linier berganda diperoleh nilai koefisien regresi sebesar 0,001 dan uji parsial variabel free cash flow diperoleh nilai thitung sebesar 1,904>t tabel 2,008 dan nilai signifikan 0,063>0,05 (dengan nilai df(n-k-1)= 51, 0,025) Hal ini menyatakan Free cash flow tidak terdapat pengaruh terhadap kebijakan dividen atau dengan kata lain hal yang menyatakan terdapat pengaruh Free cash flow yang diproksikan dengan FCF tidak diterima atau ditolak hal tersebut sejalan dengan Penelitian Arilaha (2009) yang menemukan bahwa free cash flow tidak berpengaruh terhadap kebijakan dividen. 


\section{KESIMPULAN}

Kesimpulan dari penelitian ini adalah Kepemilikan Manajerial tidak berpengaruh terhadap Kebijakan Dividen hal ini karena Semakin banyaknya saham yang dimiliki oleh manajerial maka manajemen cenderung menahan laba untuk pengembangan perusahaan. Karena dengan meningkatnya nilai perusahaan maka nilai kekayaannya sebagai individu pemegang saham akan ikut meningkat. Kepemilikan institusional berpengaruh terhadap kebijakan dividen karena kepemilikan institusional lebih mementingkan stabilitas pendapatan (return) melalui pembagian dividen sementara Free cash flow tidak Berpengaruh dengan Kebijakan Dividen karena kelebihan kas pada pemegang saham dalam bentuk dividen guna memaksimumkan kekayaan pemegang saham. Hal tersebut menunjukkan bahwa dividen dapat mengurangi agency cost karena mengurangi free cash flow bagi manajer.

\section{DAFTAR PUSTAKA}

Anggraeni, I. 2017. Pengaruh Struktur Modal dan struktur Kepemilikan Terhadap Free Cash Flow Serta Dampaknya Terhadap Dividen (Studi Empiris Pada Perusahaan-Perusahaan Yang Go Public Di Bursa Efek Indonesia). AKURAT| Jurnal Ilmiah Akuntansi FE UNIBBA 8 (2):82-92.

Anita, A., dan A. Yulianto. 2016. Pengaruh kepemilikan manajerial dan kebijakan dividen terhadap nilai perusahaan. Management Analysis Journal 5 (1).

Arilaha, M. A. 2009. Pengaruh free cash flow, profitabilitas, likuiditas, dan leverage terhadap kebijakan dividen. Jurnal Keuangan dan Perbankan 13 (1):78-87.

Ayem, S., dan R. Nugroho. 2010. Pengaruh Profitabilitas. Struktur Modal, Kebijakan Dividen, dan Keputusan Investasi terhadap Nilai Perusahaan (Studi Kasus Perusahaan Manufaktur Yang Go Publik di Bursa Efek Indonesia) PERIODE 2014.

Brigham, E. F., dan J. F. Houston. 2010. Essentials of financial management: Engage Learning Asia.

Dewi, S. C. 2008. Pengaruh kepemilikan managerial, kepemilikan institusional, kebijakan hutang, profitabilitas dan ukuran perusahaan terhadap kebijakan dividen. Jurnal Bisnis dan Akuntansi 10 (1):47-58.

Embara, C. T. D. L. 2012. Variabel-Variabel Yang Berpengaruh Terhadap Kebijakan Dividen Serta Harga Saham Pada Perusahaan Manufaktur Di Bursa Efek Indonesia. Matrik: Jurnal Manajemen, Strategi Bisnis dan Kewirausahaan.

Faizal, R. P. 2014. Ownership Structure, Tax Disclosure Dan Voluntary Nonfinancial Disclosure (Studi Pada Perusahaan di Indonesia yang terdaftar di BEI Tahun 2009-2012).

Firmanda, R., K. Raharjo, dan A. Oemar. 2015. Pengaruh Kepemilikan Manajerial, Kepemilikan Institusional, Kebijakan Hutang, Profitabilitas, Ukuran Perusahaan Dan Cash Position Terhadap Kebijakan Dividen. Journal Of Accounting 1 (1).

Gujarati, D. N., dan D. C. Porter. 2006. Dasar-dasar ekonometrika. Jakarta: Erlangga. 
Hatta, A. J. 2002. Faktor-faktor yang Memengaruhi Kebijakan Dividen. Jurnala Akuntasi dan Auditing Indonesia 6 (0):2.

Ichsan, R. 2013. Teori Keagenan. Agency Theory.

Imam, G. 2011. Aplikasi analisis multivariate dengan program IBM SPSS 19. Semarang: Badan Penerbit Universitas Diponegoro.

Ismiyanti, F., dan M. M. Hanafi. 2003. Kepemilikan Manajerial, Kepemilikan Institusional, Risiko, Kebijakan Utang dan Kebijakan Dividen: Analisis Persamaan Simultan. Simposium Nasional Akuntansi VI:260-277.

Jensen, M. C. 1986. Agency costs of free cash flow, corporate finance, and takeovers. The American economic review 76 (2):323-329.

Kahar, S. H. A. 2008. Kepemilikan Manajerial Terhadap Kebijakan Pendanaan dan Dividen. Jurnal Keuangan dan Perbankan 12 (3):399-410.

Keown, A. J. 2004. Foundations of finance: The logic and practice of financial management: 清华大学出版社有限公司.

Kurniawan, H. 2011. Analisis Kelayakan Pengembangan Bimbingan Belajar Nurul Fikri Pada Aspek Pasar, Aspek Pemasaran Dan Aspek Keuangan Di Daerah Panam Pekanbaru, Universitas Islam Negeri Sultan Syarif Kasim Riau.

Kurniawati, L., S. Manalu, dan R. J. N. Octavianus. 2015. Pengaruh Kepemilikan Institusional Terhadap Kebijakan Dividen, Dan Harga Saham. Jurnal Manajemen Maranatha 15 (1).

Laili, M., N. A. S. Darmawan, A. SE, dan N. K. SINARWATI. 2015. Pengaruh Debt To Equity Ratio, Kepemilikan Manajerial, Return On Assets, Dan Current Ratio Terhadap Dividend Payout Ratio (Studi Empiris pada Perusahaan Manufaktur yang Terdaftar di BEI Periode 2009-2013). JIMAT (Jurnal Ilmiah Mahasiswa Akuntansi) Undiksha 3 (1).

Listyani, T. 2003. Kepemilikan manajerial dan pengaruhnya terhadap kepemilikan saham institusional. Jurnal Politeknik Negeri Semarang 3.

Martono, N. 2015. Metode penelitian sosial: konsep-konsep kunci. Jakarta: PT RajaGrafindo Persada.

Mirza, H. H., dan T. Azfa. 2010. Ownership structure and cash flows as determinants of corporate dividend policy in Pakistan. International Business Research 3 (3):210-221.

Mollah, S., K. Keasey, dan H. Short. 2000. The influence of Agency costs on dividend policy in an emerging market: Evidence from the Dhaka stock Exchange. Paper read at Paper of Workshop at the University of Oslo Norway.

Mulyono, B. 2009. Pengaruh debt to equity ratio, insider ownership, size dan investment opportunity set terhadap kebijakan dividen (studi pada industri manufaktur yang terdaftar di Bursa Efek Indonesia periode tahun 2005-2007), UNIVERSITAS DIPONEGORO.

Nekounam, J., H. R. M. Hossini, dan M. Ahmadi. 2013. Relationship between institutional ownership and agency cost in investing market of Iran. Life Science Journal 10 (6s):34-38.

Nidar, S. R. 2014. Analisis Struktur Modal, Kebijakan Dividen, dan Volatilitas Pendapatan terhadap Kinerja Emiten Terbaik. Trikonomika Journal 9 (2):105-112. 
Nurdiana, N. 2007. Analisis Pengaruh Free cash flow, kepemilikan manajerial, kebijakan utang, dan return on aseets terhadap kebijakan dividen. Skripsi. Jurusan manajemen. Universitas Brawijaya. Malang.

Purnomo, D. Y. 2008. Pengaruh ukuran perusahaan, pertumbuhan aktiva dan profitabilitas terhadap hutang dan pengaruh hutang terhadap return saham (Studi Kasus Pada Perusahaan Manufaktur Go Public di Bursa Efek Jakarta Tahun 2001-2006), UNS (Sebelas Maret University).

Rachmawati, A. A., dan N. Handayani. 2014. Pengaruh Rasio Keuangan dan Kebijakan Dividen terhadap Pertumbuhan Laba pada Perusahaan Manufaktur yang Terdaftar di BEI. Jurnal Ilmu \& Riset Akuntansi 3 (3):1-15.

Rozeff, M. S. 1982. Growth, beta and agency costs as determinants of dividend payout ratios. Journal of financial Research 5 (3):249-259.

Sasongko, H., dan F. Shaliza. 2018. Pengaruh Leverage, Profitabilitas, dan EVA Terhadap Return Saham Pada Industri Makanan Dan Minuman Yang Terdaftar Di Bei Tahun 2012-2016. Jurnal Ilmiah Akuntansi Fakultas Ekonomi 4 (1):51-64.

Setiana, E. 2013. Pengaruh Free Cash Flow dan Kepemilikan Manajerial terhadap Kebijakan Hutang pada Perusahaan Manufaktur yang Terdaftar di Bursa Efek Indonesia (BEI). Jurnal Telaah Akuntansi 15 (01):16-33.

Shepherd, C. W., dan D. F. Scott Jr. 1975. Corporate dividend policy: Some legal and financial aspects. Am. Bus. LJ 13:199.

Tandelilin, E. 2010. Portofolio dan Investasi: Teori dan aplikasi: Kanisius.

Tandelilin, E., dan T. Wilberforce. 2002. Can Debt and Dividend Policies Substitute Insider Ownership In Controlling Equity Agency Conflict? Gadjah Mada International Journal of Business 4 (2002).

Wulandari, N. 2006. Pengaruh indikator mekanisme corporate governance terhadap kinerja perusahaan publik di Indonesia. Fokus Ekonomi: Jurnal Ilmiah Ekonomi 1 (2). 